\title{
Pigment Compositions and Phylogenetic Positions of Filamentous Bacteria Coexisting in Marine Microalgal Cultures
}

\author{
TAKESHI YoshiKaWA ${ }^{1 *}$, KOZO IWAMOTO $^{1}$ and TAIZO SAKATA ${ }^{1}$ \\ ${ }^{1}$ Laboratory of Microbiology, Department of Applied Biochemistry and Technology of Aquatic Resources, \\ Faculty of Fisheries, Kagoshima University, Shimoarata 4-50-20, Kagoshima, 890-0056, Japan
}

(Received May 12, 2000_-Accepted January 5, 2001)

The sequences of small subunit ribosomal RNA gene (SSU rDNA) and pigment composition were examined for the five filamentous bacteria isolated from the unialgal cultures of marine microalgae Chattonella marina, Heterosigma akashiwo, or Tetraselmis sp. The SSU rDNA data suggested that the filamentous bacteria were clustered into the same species, which belonged to the Roseobacter group in $\alpha$-proteobacteria. Sequence similarities of SSU rDNA to each of the other strains were more than $99 \%$. The strains possessed bacteriochlorophyll $a$, but were different in carotenoid composition: four of the strains contained a carotenoid that was similar to spheroidenone but the other one did not.

Key words: filamentous bacteria, marine microalgae, bacteriochlorophyll $a$, SSU rDNA, aerobic photosynthetic bacteria

We have previously reported that some bacteria in multicellular filament form were predominant in the unialgal cultures of raphidophytes Heterosigma akashiwo, Chattonella marina, and a prasinophyte Tetraselmis sp. ${ }^{12,14)}$ The bacteria formed rhizoidal colonies that were whitish pink or greenish yellow on agar plate media. The whitish pink filamentous bacteria enhanced the growth of $C$. marina cells ${ }^{13)}$. Although the phenotypic characteristics of the filamentous bacteria were similar to those of the genus Flexibacter, DNA/DNA homologies of the bacteria to the species of Flexibacter were very low ${ }^{12)}$. In this report, we examined the sequences of the small subunit ribosomal RNA gene (SSU rDNA) and the pigment composition of the filamentous bacteria to elucidate the phylogenetic positions of the filamentous bacteria.

The whitish pink filamentous bacterial strains, F190-32, F193-3, F195-1, and F196-1, were isolated from the unialgal cultures of raphidophytes, C. marina, H. akashiwo, and a prasinophyte Tetraselmis sp., and the greenish yellow bac

\footnotetext{
*Corresponding author; E-mail: yoshi@fish.kagoshima-u.ac.jp, Tel: +81-99-286-4192, Fax: +81-99-286-4192

Abbreviations: bchl, bacteriochlorophyll; RFLP, restriction fragment length polymorphism; PCR, polymerase chain reaction; SSU rDNA, small subunit ribosomal RNA gene.
}

terial strain, F195-5R (formerly termed F195-5), was isolated from $H$. akashiwo ${ }^{12,14)}$. Carotenoids were extracted from the bacterial cell pellets with ethanol for $24 \mathrm{~h}$ at $4^{\circ} \mathrm{C}$. The extract was shaken with a twofold volume of a mixture of acetone/ $n$-hexane $(2: 1)$. The hexane phase was washed 10 times with water, and evaporated on dried anhydrous sodium sulfate. The pigment was re-dissolved in petroleum ether. Bacteriochlorophyll (bchl) was extracted according to the method described by Shiba et al. ${ }^{9}{ }^{\text {. }}$. The absorption spectra of the pigments were determined using a spectrophotometer, MPS-2000 (Shimadzu, Japan).

DNA was extracted according to the method of Sukoso et al. ${ }^{14)}$. Polymerase chain reaction (PCR) amplification of SSU rDNA was carried out based on the method previously reported $^{3)}$, with a pair of the oligonucleotides ${ }^{3)}$. PCR-amplified DNA fragments were subjected to the restriction fragment length polymorphism (RFLP) analysis with AluI, $B s u$ RI, MspI, and SmaI. The nucleotide sequences were also determined in the products cloned into a plasmid vector, pT7Blue (R) (Novagen, USA), with the genetic analyzer ABI PRISM 310 (PE Biosystems, USA) using the BigDye Terminator Cycle Sequencing Kit (PE Biosystems, USA).

The accession number of F190-32 sequence in DDBJ is AB046591. Multiple sequence alignment, genetic distance 


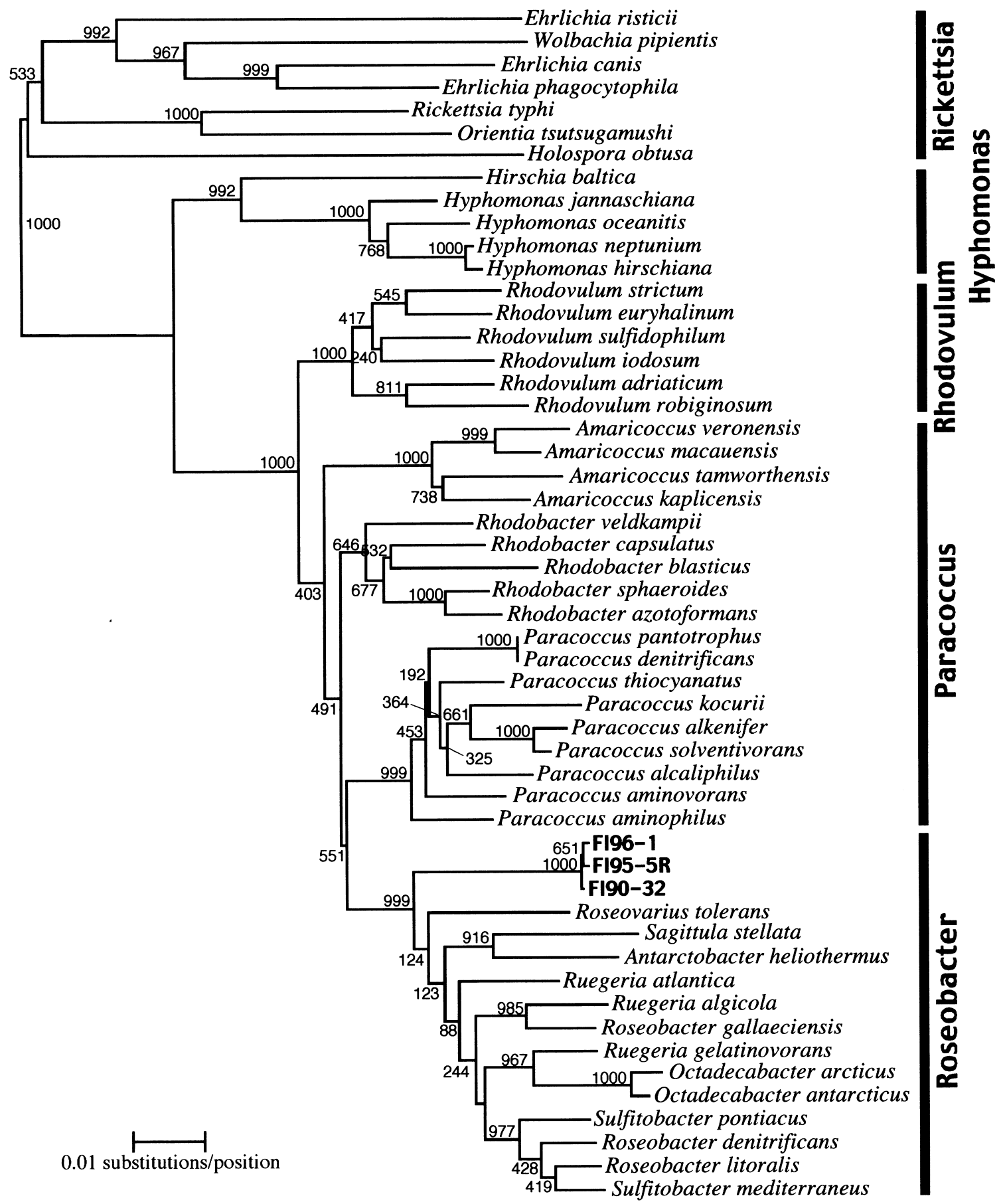

Fig. 1. Phylogenetic relationship inferred from the SSU rDNA sequence similarities. The phylogenetic tree was constructed using the neighborjoining method ${ }^{8}$. The bootstrap values are indicated at the branching points. The phylogenetic groups of the $\alpha$-proteobacteria are also shown. 

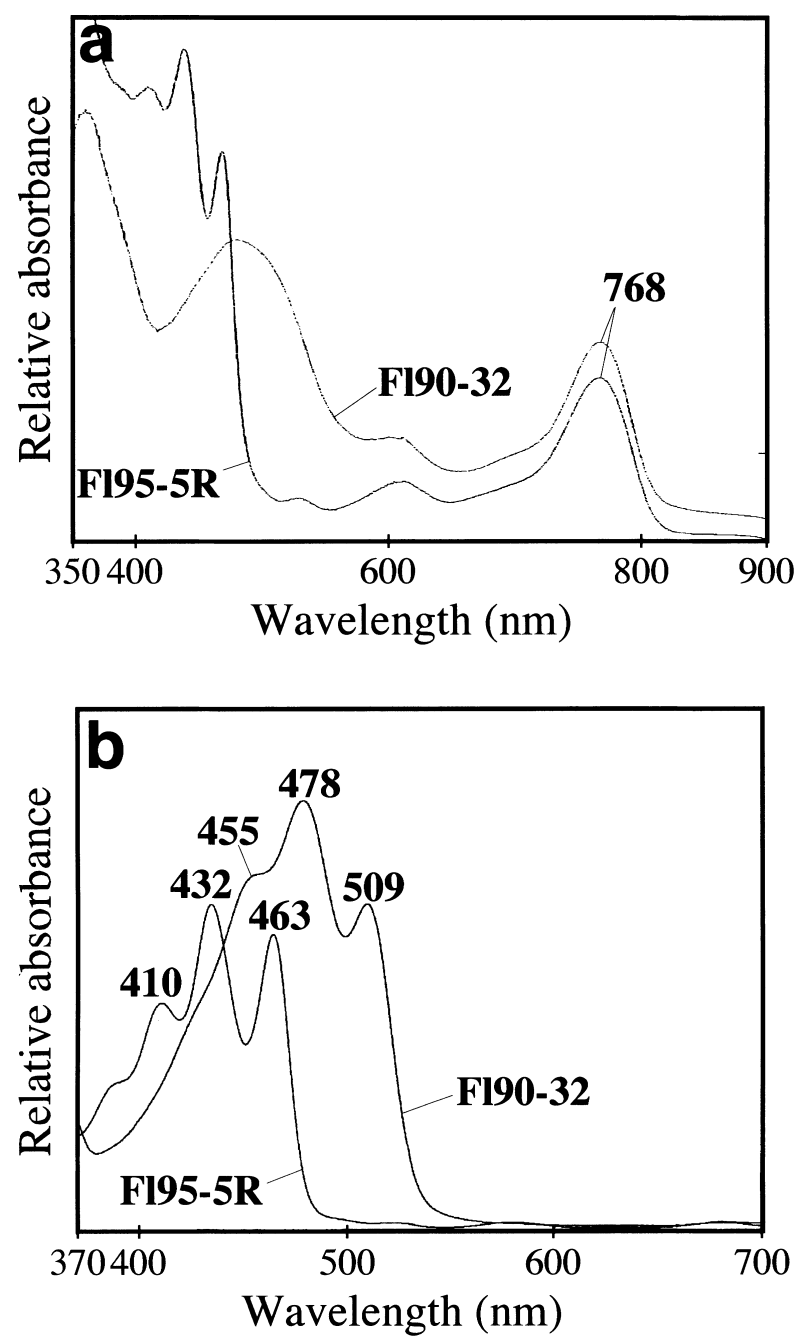

Fig. 2. Absorption spectra of methanol extract (a) and carotenoid fraction (b) of the cells of the filamentous bacterial strains F19032 and F195-5R. The carotenoid fractions were dissolved in petroleum ether. The wavelengths of the absorption maxima are indicated in the figures.

calculations with Kimura's 2-parameter method ${ }^{5)}$, bootstrap resamplings ${ }^{2)}$, and phylogenetic tree constructions by Nei and Saitou's neighbor-joining method ${ }^{8)}$ were performed by the program Clustal W version 1.8 ${ }^{15}$.

The PCR-amplified SSU rDNA of the five strains gave indistinctive RFLP patterns (data not shown). The SSU rDNA nucleotide sequences of F190-32, F195-5R, and F196-1, whose lengths were $1274 \mathrm{bp}$, corresponding to the Escherichia coli numbers 49-1400, also showed almost the identical sequences and their similarity values were more than $99 \%$. Therefore, we speculated that the five strains were part of the same species.

The phylogenetic tree in Fig. 1 showed that the filamen- tous bacterial strains were closely related to the Roseobacter group containing the genera Roseobacter ${ }^{11)}$ and Roseovarius $^{6}$, which indicates the close phylogenetic relationship between the filamentous bacteria and the bchl $a$ containing aerobic photosynthetic bacteria ${ }^{10)}$.

Figure 2a shows absorption spectra of the crude methanol extract of the filamentous bacterial cells. The spectra of F190-32 and the other three strains show three absorption peaks at $768 \mathrm{~nm}$, around $500 \mathrm{~nm}$, and $364 \mathrm{~nm}$. The peaks at 768 and $364 \mathrm{~nm}$ are characteristics of bchl $a^{7}$, and the peak around $500 \mathrm{~nm}$ seems to indicate the presence of carotenoid. The spectrum of F195-5R is similar to that of F190-32 in the peaks at 768 and $364 \mathrm{~nm}$ but different in the peak at around $500 \mathrm{~nm}$. Hence, we speculated that all of the filamentous bacteria contained bchl $a$.

Possible carotenoid fraction was purified by the partition between ethanol and the mixture of acetone/ $n$-hexane $(2: 1)$. The absorption spectra obtained for the hexane fraction indicated only the peaks around $500 \mathrm{~nm}$ but not the peak at $364 \mathrm{~nm}$ or $768 \mathrm{~nm}$ (Fig. 2b). The absorption spectra of the major pigment of the whitish pink bacteria in petroleum ether indicated three peaks at 455, 478, and $509 \mathrm{~nm}$. These absorption maxima coincided with the major carotenoid of Rhodobacter sphaeroides IFO12203 (455, 478, and 509 $\mathrm{nm})$ and were similar to spheroidenone (460, 483, and 515 $\mathrm{nm}$ in light petroleum ${ }^{1)}$ or petroleum ether $\left.{ }^{4}\right)$. On the other hand, the greenish yellow strain F195-5R showed no similarity to the others: the spectrum of the pigment from F195$5 \mathrm{R}$ had the absorption maxima at 410, 432, and $463 \mathrm{~nm}$ (Fig. 2b).

In conclusion, all of the whitish pink and greenish yellow filamentous bacteria, which were predominant in the cultures of H. akashiwo, C. marina, or Tetraselmis sp., belonged to a species that was included in the Roseobacter group in $\alpha$-proteobacteria. The sequence similarities of SSU rDNA to each of the other strains were more than $99 \%$. Although the carotenoid spectra of the whitish pink and the greenish yellow bacteria were different from each other, the phylogenetic meaning of the difference cannot be elucidated without information on the chemical structure. We have not yet obtained any data on the photosynthetic activity of the filamentous bacteria, although it has been confirmed that the bacteria contained bchl $a$.

\section{Acknowledgement}

We wish to thank Dr. T. Uchiumi (Faculty of Science, Kagoshima University) for operating the genetic analyzer. 


\section{References}

1) Britton, G. 1995. UV/visible spectroscopy. pp. 13-62. In G. Britton, S. Liaaen-Jensen and H. Pfander (ed.), Carotenoids. Volume 1B: Spectroscopy. Birkhäuser Verlag, Switzerland.

2) Felsenstein, J. 1985. Confidence limits on phylogenies: an approach using the bootstrap. Evolution. 39: 783-791.

3) Iwamoto, K., T. Yoshikawa and T. Sakata. 2000. DNA-DNA hybridization and RFLP analysis of algicidal filamentous bacteria isolated from marine environments. Suisanzoshoku. 48: 123-130.

4) Jensen, S.L. 1963. Bacterial carotenoids. X. On the constitution of the minor carotenoids of Rhodopseudomonas. 1. P518. Acta Chem. Scand. 17: 303-312.

5) Kimura, M. 1980. A simple method for estimating evolutionary rates of base substitutions through comparative studies of nucleotide sequences. J. Mol. Evol. 5: 111-120.

6) Labrenz, M., M.D. Collins, P.A. Lawson, B.J. Tindall, P. Schumann and P. Hirsch. 1999. Roseovarius tolerans gen. nov., sp. nov., a budding bacterium with variable bacteriochlorophyll $a$ production from hypersaline Ekho Lake. Int. J. Syst. Bacteriol. 49: 137-147.

7) Oelze, J. 1985. Analysis of bacteriochlorophylls. Meth. Microbiol. 18: $257-284$.

8) Saitou, N. and M. Nei. 1987. The neighbor-joining method: A new method for reconstructing phylogenetic trees. Mol. Biol. Evol. 4: 406-425.

9) Shiba, T., U. Simidu and N. Taga. 1979. Distribution of aerobic bacteria which contain bacteriochlorophyll $a$. Appl. Environ. Microbiol. 38: 43-45.

10) Shiba, T. and K. Harashima. 1986. Aerobic photosynthetic bacteria. Microbiol. Sci. 3: 376-378.

11) Shiba, T. 1991. Roseobacter litoralis gen. nov., sp. nov., and Roseobacter denitrificans sp. nov., aerobic pink-pigmented bacteria which contain bacteriochlorophyll $a$. Syst. Appl. Microbiol. 14: $140-145$.

12) Sukoso and T. Sakata. 1996. Effect of co-existent bacteria on the growth of Chattonella marina in non-axenic culture. Fisheries Sci. 62: 210-214.

13) Sukoso, T. Yoshikawa and T. Sakata. 1997. Effect of filamentous bacteria on the growth of Chattonella marina. Mem. Fac. Fish. Kagoshima Univ. 46: 31-37.

14) Sukoso, K. Iwamoto, T. Sakata and T. Yoshikawa. 1998. Characteristics of filamentous bacteria co-existing with some marine microalgae. Fisheries Sci. 64: 65-70.

15) Thompson, J.D., D.G. Higgins and T.J. Gibson. 1994. CLUSTAL W: improving the sensitivity of progressive multiple sequence alignment through sequence weighting, position specific gap penalties and weight matrix choice. Nucl. Acids Res. 22: 4673-4680. 